\title{
Community praxis: Exploring a community engagement framework for restorative justice in British Columbia, Nova Scotia, and Bangladesh
}

\author{
Muhammad Asadullah*
}

\begin{abstract}
The concept of community is pervasive but ambiguous, and there is a lack of research on the role of community in restorative justice. Employing both in-depth qualitative interviews and surveys, this qualitative study unearths the role of community in restorative justice in British Columbia, Nova Scotia, and Bangladesh and examines existing community praxis in those places. The study proposes a community engagement framework which consists of horizontal community and vertical community. The study argues that incorporation of both horizontal and vertical communities would strengthen the quality of relationships, while also fostering innovation and creativity in restorative justice.
\end{abstract}

Key Words Horizontal community; vertical community; reflective community; learning community.

\section{INTRODUCTION}

Community has been vigorously studied and is deeply embedded in classical theories and discourses. The idea of community evokes diverse images, interpretations, roles, and metaphors. Yet, whilst the concept of community is pervasive, there is ambiguity surrounding exactly what community is and what its roles are or should be. Definitions and descriptions include the following:

Community may connote "connectedness" of individuals and groups (Bolivar, 2012, p. 17).

- Day (2006, p. 2) explains community as "group-ness" where "people do things... together rather than separate and alone."

- Community can refer to a place where a group of people feel a sense of belonging and connection (Karp \& Clear, 2002).

- Community can be defined when individuals experience a sense of belonging (Block, 2018). The state of belonging is thus seen to have both a physical and an emotional dimension.

In short, interconnectedness, belonging, and togetherness are essential traits of community. Community is fluid, residing in "those things which people have in common, which bind them together, and give them a sense of belonging with one another" (Daly, 2016, p. 1). The diverse ways that community has been understood and operationalized has problematized community as a contested construct, revealing fundamental assumptions and aspirations about community (Bolivar, 2012).

In the context of restorative justice, community has been regarded as the "center" and "driving force" (DicksonGilmore \& LaPrairie, 2005, p. 3). This is why Gavrielides \& Artinopoulou (2013, p. 38) posited Restorative Justice (RJ) as "community born and community led." Scholarship on the idea of community in RJ has substantially increased in recent years (see Block, 2018; Dzur \& Olson, 2004; Elliott, 2011; McCold, 2010; Rosenblatt, 2015). Nonetheless, there is a "significant deficiency" in defining and operationalizing the notion of community in RJ (Bolivar, 2012, p. 18). Some commonly practiced community roles for RJ are volunteers, board members, and supporters for victims and offenders (Maglione, 2017).

Using both in-depth qualitative interviews and surveys, this study explores the concept of community in the context of restorative justice in British Columbia, Canada (BC), Nova Scotia, Canada (NS), and Bangladesh (BD). Existing community praxis in RJ includes community as volunteer,

Correspondence to: Dr. Muhammad Asadullah, Department of Justice Studies, University of Regina, 3737 Wascana Pkwy, Regina, SK S4S OA2.

E-mail: Muhammad.Asadullah@uregina.ca

To cite: Asadullah, M. (2020). Community praxis: Exploring a community engagement framework for restorative justice in British Columbia, Nova Scotia, and Bangladesh. Journal of Community Safety and Well-Being, 5(3), 110-119. https://doi.org/10.35502/jcswb.125

(C) Author(s) 2020. Open Access. This work is distributed under the Creative Commons BY-NC-ND license. For commercial re-use, please contact sales@sgpublishing.ca.

gPUBLISHING Published by SG Publishing Inc. CSKA Official publication of the Community Safety Knowledge Alliance. 
community as neighbour, and community circle of support (Dzur \& Olson 2004; McCold, 2010). This study finds both common and distinctly different community praxis in BC, $\mathrm{NS}$, and BD. For example, findings from BC offer the concept of reflective community in which bonding and relationshipbuilding were central themes. In NS, the learning community is a form of community praxis that focuses more on mutual learning and sharing about what is working, what is not working, and what can be done to address newer challenges. Bangladesh, on the other hand, applied a different form of community praxis in the form of Community-Based Organization (CBO). CBOs, differ from non-government organizations (NGOs) in Bangladesh in that they are mostly locally grown organizations, whereas NGOs are nationally run. The survey participants in Bangladesh believe that the involvement of CBOs is important to the future of RJ in Bangladesh.

In light of the findings on community praxis from BC, NS, and BD, this study proposes a Community Engagement Framework with two key components: horizontal community and vertical community. The horizontal community in $\mathrm{RJ}$ consists of a) reflective community, and b) community as neighbour, while the vertical community is more formal and structural, and includes a) learning community, b) circle of care, and c) community as volunteer. This study concludes that incorporating both the horizontal and vertical communities in RJ would strengthen the quality of relationship, while also fostering innovation and creativity.

\section{LITERATURE REVIEW}

Normative understandings of community vary from scholar to scholar. The literature begins with a brief overview of classical theories on the idea of community from Durkheim and Tönnies because of their resonance with community praxis.

\section{Classical Theories on Community}

\section{Emile Durkheim}

Sociologist Emile Durkheim, one of the earliest classical scholars, used a social solidarity lens to demarcate community. In his book The Division of Labor, Durkheim outlines two types of community: a) mechanical community, and b) organic community. Community can be established as a form of solidarity founded on a premise of "states of conscience which are common to all members of the same society" (Durkheim, 1933, p. 109). Community can also be formed on the basis of an interdependency and complementarity referred to as "organic" (Durkheim, 1933, p. 129). According to McKinney (1966), Durkheim's categorization of mechanical and organic ways of forming social solidarity is more of a normative idea and may thus be different in practice. Additionally, Day (2006, p. 3) views Durkheim's approach to social solidarity as relevant to our current understanding of contrasting social orders: "a normative preoccupation with the regulation of society to maintain successful cooperation, and a sense of fear that prevailing social conditions might render this impossible." The historical context of industrialization and emergent individualism shaped Durkheim's concept of social solidarity and its categorization into mechanical and organic (Day, 2006; Perry, 1986).

\section{Ferdinand Tönnies}

Ferdinand Tönnies, the German philosopher and sociologist, played the most instrumental role in theorizing the notion of community as it pertains to social solidarity. In his book Community and Society (1957), he outlines a comparative analysis of Gemeinschaft (community) and Gesellschaft (society). According to Tönnies, Gemeinschaft is defined as a "lasting and genuine form of living together" in which the connection among people is much more organic and alive, whereas Gesellschaft is a state in which individuals are involved with each other through a "transitory and superficial" connection (Tönnies, 1957, p. 35). Community, according to Tönnies (1957), deeply connects people with each other through kinships and relationships and proximity. An example of this is people living in villages, rural areas, or small communities.

In summary, Durkheim and Tönnies each offer two types of community: mechanical community and organic community (Durkheim) and Gemeinschaft and Gesellschaft (Tönnies). Organic community and Gemeinschaft share some similarities, as do Gesellschaft and mechanical community.

\section{Community Praxis}

Promoted by Freire (1972, pp. 75-76), the idea of praxis indicates both "action and reflection." Prilleltensky (2001, p. 758) argues that praxis is "unity of theory and action." Moreover, he proposes four key elements of praxis: a) balance between philosophical and grounded input, b) balance between understanding and action, c) balance between process and outcome, and d) balance between differing and unequal voices. Blodgett et al. (2008, p. 393) view praxis as "the cyclical process of reflection and action, and theory and practice that is motivated by a commitment to transformation through social activism." They propose four key features of praxis, particularly in research settings: a) pursuit of lines of inquiry that are meaningful to the participants; b) utilization of culturally sensitive strategies; c) involvement of participants in the project's development, analysis, and dissemination; and d) use of consensus decision-making models (Blodgett et al., 2008, p. 412). Praxis can also be defined as a convergence of reflection and practices (Lederach, 1997). In short, praxis is a "critico-practical activity whereby theory must be put into action to be made meaningful" (Osborne, 2017, p. 847).

In a community setting, praxis includes theorizing ideas, coordinated action by practitioners, and reflection by community members (Evans, 2015). Community praxis implies practices that are grounded in theory. Historically, theory and practice were not "intrinsically divorced" from the idea of community (Anderson \& Freebody, 2012, p. 360). Morrison and Vaandering (2012, p. 145) define community praxis as the engagement of "rich ecologies of individuals' lives, at the social and emotional level of a community." In summary, the essence of praxis is the cyclical convergence of theory, practice, and reflection.

\section{Community in the Context of Restorative Justice}

In the context of RJ, community is defined as people directly or indirectly connected with the person harmed or the one who caused the harm. These people may be relationally or geographically connected with the victims or offenders. Community can also be defined as the specific geographical setting in which a restorative justice organization is located 
(Dhami \& Joy, 2007; McCold, 2010). Community volunteers help return crime to the main stakeholders, resulting in deprofessionalization. Micro community, also known as the circle of care for victims and offenders, offers emotional support, inspiration, and encouragement. It contributes to the social capital of victims and offenders. Macro community, on the other hand, provides material support. Through these elements, justice stakeholders-offenders in particular-can be connected and reintegrated with the larger community (Maglione, 2017; McCold, 2010).

Grounded in Christie's (1977) analysis of conflict as property and the importance of participatory norm clarification through returning conflict to the community, RJ practices have operationalized community in a range of modalities; community as providers and facilitators; community as circles of care and participants; and community as neighbourhood. A number of theories influenced the formation of these community frameworks, including reintegrative shaming theory (Braithwaite, 1989), relational justice theory (Llewellyn, 2011), social identity theory (Morrison, 2006), procedural justice theory (Tyler \& Blader, 2000), and conflict transformation theory (Lederach, 1997).

According to Zehr's restorative lens, community involvement is foundational to restorative justice because of its emphasis on collective and communal responses to harm and wrongdoing, as opposed to individual or state-based responses (Pavlich, 2010). Pranis (1995) summarizes the importance of community inclusion in restorative justice:

Greater community involvement in a restorative justice process is a powerful way to break this destructive cycle and increase the connections among community members. The more connected with each other community members are, the more likely they will be to restrain impulses which would be disapproved by the community. (para. 72)

Finally, Peter Block defines a "restorative community" as one that produces a certain "quality of aliveness and wholeness" (Block, 2018, p. 49). According to him, a restorative community in practice is given by "language of connection, relatedness and belonging" (p. 50). Yet the operationalization of community within RJ remains vague and defies complexity, in both definition and praxis. In the context of restorative justice and responsive regulation, Burford (2018) encourages regulators and practitioners "to engage with complexity" and shared that:

Organizational culture often conflates the governance of formalism and responsivity, undermining the capacity of people to influence policy, practice and decision making. The key message is that culture needs to be understood as, among other things, complex relational-emotional space which can be embodied only though approaches that embrace listening and dialog. Restorative approaches coupled with regulatory theory are used to show how grappling with complexity can be a driver of positive change in culture and re-center the state's role as a competent, ethical partner alongside other non-state and informal actors. (p. 366)

\section{Community as Providers and Facilitators}

Braithwaite (2002) argues that the involvement of community is important to active citizenship wherein the system is deprofessionalized to include actors beyond the typical justice actors (i.e., police, lawyers, judges, and correctional officers). The role of community as an active provider shifts the enactment of justice beyond the purview of professionals; it shifts citizens out of a 9-1-1 mentality in which they are bystanders to crime and conflict who expect professionals to take care of the problem. Retired judge Barry Stuart of the Territorial Court of the Yukon was critical of the professionally exclusive nature of the justice system:

Despite a widespread, long standing appreciation that we cannot remove crime from communities solely be removing criminals, and that the State can never effectively replace the contributions to well-being made by families and communities, we persist in desperately trying to do so. This is our "March of Folly." (1998, p. 90)

Baskin and Sommers (1990) consider community participation the "democratization of justice" (p. 251), which essentially returns ownership and control of the crime to the community and the people who are affected by it, not to the state or professionals. Lofton (2010) holds that harms occur due to the community's "lack of wholeness" (p. 385) and inaction, and active involvement of the community is a prerequisite to restoring wholeness and operationalizing the holistic focus of restorative justice.

When community is operationalized within this framework, the community is made stronger and further harm is prevented; the restorative justice process can reunite what has been divided; and community members can participate in the process of clarifying norms and building consensus.

Community as Circles of Care, Support, and Accountability Participants in restorative justice processes, particularly those who have been victimized and/or have offended, often attend with their respective communities of care. McCold (2010) termed this type of community a micro community, and it comprises those who have "meaningful personal relationships" with the victim(s) and offender(s) (p. 156). A circle of care thus includes family members, friends, and significant others of the victims and offenders (Maglione, 2017; Rossner \& Bruce, 2016). Pranis (2007) argues that the community acts as a resource for victims and offenders whereby they can hold each other accountable to certain values and principles.

Grounded in Braithwaite's (2000) reintegrative shaming theory, a healing-centred restorative justice process allows victims and offenders to express emotion and also hear from the community members they care for the most about the impact of the harms (Abramson \& Beck, 2010). The presence of community offers a safe container within which victims and offenders can express their frustrations and anger. Karp and Clear (2002) view community both as a place and a relationship. On the same note, Schatz (2013) sees the community's role as a "glue" that nurtures partnership (p. 114). Ensuring both vertical (to the state) and 
horizontal (to person(s) and community harmed) accountability facilitates transformational processes in restorative justice (Roche, 2003).

When community is operationalized within this framework, the community is made stronger and further harm is prevented at a family (or micro) level; the restorative justice process can create a container to heal what has been broken within families; the community can lead a process that seeks full and direct accountability.

\section{Community as Neighbourhood}

The community in which a harm was committed is also an important element of the restorative justice process. McCold (2010) coined this type of community a macro community. Community in this context is tied to a geographic location. People in macro communities are usually connected via space, shared values, ethnicity, faith traditions, and mutual interests (Bolivar, 2012; Gerkin, 2012).

Active engagement of the volunteers, board members, and local citizens in a restorative justice organization can foster social cohesion and contribute towards community building. For example, Roca, an NGO in Massachusetts, in the United States, which is grounded in restorative justice principles and values, successfully transformed communities by using circle processes (Beck, 2012). According to Green et al. (2013), a restorative city is "a vision where the adoption of restorative values, principles, and language inspires its young to grow into forward-looking, articulate, and empowered adults who will shape the future of their city" (p. 447). Rossner and Bruce (2016) conducted empirical studies in order to examine the role of community in RJ conferences in New South Wales, Australia. They conducted 100 interviews, analyzed documents from 204 conferences, and completed 34 participant observations. They conclude that the success of RJ conferences depends largely on the degree of community engagement and consultation at all levels-communities of care, volunteers, and local community members (Rossner \& Bruce, 2016). Safe neighbourhoods are restorative; they invite full participation and consensus; heal what has been broken; seek full and direct accountability; reunite what has been divided; and strengthen the community, to prevent further harms at all levels of regulation and governance.

There are gaps in the literature in relation to explorations of community praxis in restorative justice. This is noteworthy given that several authors view community as a fundamental feature of restorative justice (Gavrielides \& Artinopoulou, 2013; Morrison \& Vaandering, 2012). Bolivar (2012) considers the lack of research on the role of community a "significant deficiency" (p. 18) for RJ theory and practice, whilst Walgrave (2008) blames the vagueness of the notion of community for this gap in empirical studies. Even though community, albeit vaguely understood, is an integral part of RJ ethos, theory, and practice, the operational understanding of community praxis therein is limited (Morrison et al., 2020). This study addressed this gap by asking, What is the role of community in restorative justice in British Columbia, Nova Scotia, and Bangladesh? In answering this research question, it also examines existing community praxis such as community as volunteer, community as neighbour, and community as circle of care.

\section{METHODOLOGY}

This study was approved by Simon Fraser University's Research Ethics Board and employed qualitative methods for data collection and analysis. A method is defined as a way of conducting research and the process of utilization of research instruments (Hesse-Biber, 2010). As mentioned earlier, this research is largely grounded in qualitative methods, which offer active engagement between the researcher and the participants. Key qualitative methods-in-depth qualitative interview and surveys-were used. These qualitative instruments not only unearth phenomena, they also provide ways to explore "deeper and more genuine expressions of beliefs and values that emerge through dialogue [and] foster a more accurate description of views held" (Howe, 2004, p. 54). The three research sites-BC, NS, and BD-were selected based on phenomenological criteria: in all three settings, there are examples of restorative justice practices and contrasting factors that contributed to the growth of RJ. Convenience also played a role in site selection: the researcher knows several gatekeepers and has social capital in the three settings chosen. Without gatekeepers, it is challenging for researchers to access participants (Broadhead \& Rist, 1976). Ten key informantsfour from BC and three each from NS and BD—shared their reflections on RJ and community in interviews, and 50 survey participants responded to a questionnaire on the role of community in RJ (Table I). Key informants are identified by their site and a random number (i.e., Participant BC \#3, 12, 18, Participant NS \#2, 4, 8, and Participant BD \#2, 4, 5). Research participants were selected using both snowball and purposive sampling methods. All interviews were recorded digitally and transcribed. SurveyMonkey and NVivo software were employed for data collection and data analysis.

There are two key factors that made this research challenging. First, fieldwork required expenses including plane fare, accommodation, and food. Because this research was not funded by any grants, the fieldwork duration was limited. Second, getting access to participants from three different communities was challenging. The researcher faced particular challenges in getting access to participants in Bangladesh; many, especially those working for international NGOs (INGOs), had schedules that were very full. For example, the

TABLE I Key informant interviewees and survey participants

\begin{tabular}{lcccc}
\hline \multicolumn{1}{c}{ Research Site } & $\begin{array}{c}\text { Number of Key-informant } \\
\text { Interviewees }\end{array}$ & Pseudonyms & $\begin{array}{c}\text { Number of Survey } \\
\text { Participants }\end{array}$ \\
\hline British Columbia (BC) & 4 & Participant BC 3, Participant BC 4, Participant BC 12, Participant BC 18 & 20 \\
Nova Scotia (NS) & 3 & Participant NS 2, Participant NS 4, Participant NS 8 & 14 \\
Bangladesh (BD) & 3 & Participant BD 2, Participant BD 4, Participant BD 5 & 16 \\
\hline
\end{tabular}


researcher had to reschedule one interview five times due to the hectic work schedule of the interviewee.

\section{RESULTS AND DISCUSSION}

This study found three types of communities in BC, NS, and BD: community as volunteer, community as circles of care, and community as neighbour. The study also revealed two additional types of community praxis in RJ-reflective community and learning community-and proposes a community engagement framework that combines all types of community praxis.

\section{Existing Community Praxis in Restorative Justice}

\section{Community as Volunteers}

Community volunteers play an important role in the area of facilitation and mediation. Many RJ practices around the world depend largely on community volunteers. These community volunteers act as a "neutral third party" in RJ organizations (Rossner \& Bruce 2016, p. 108). They also contribute as board members of such organizations or as part of a reparation board (Dhami \& Joy, 2007; Gerkin, 2012; Karp \& Drakulich, 2003). If successfully engaged, local community members can act as key stakeholders in RJ practices (Schatz, 2013).

Across all three research sites, volunteers played a significant role in the growth of RJ. When asked to rank factors that contributed to the growth of RJ, the majority of survey participants in BC and NS identified volunteers as "very important" to the growth of RJ, and in BD, still 31\% identified volunteers as very important (see Table II).

\section{Community as Circles of Care}

This study finds existence of circles of care or micro community in all sites-BC, NS, and BD. Key informants, such as Participant BC 18, Participant NS 4, and Participant BD 5, confirmed that their RJ practices include victims, offenders, and their supporters. In BC, for example, RJ programs are "strongly encouraged" to include victims, offenders, and their supporters in RJ practices by funds such as the provincial community accountability program (Participant BC 18). In NS, a common practice by many programs includes a circle of support or healing circle for victims (Participant NS 4). Similar to those in BC and NS, RJ programs in BD also include victims, offenders, and their supporters in RJ practices, as Participant BD 5 described: "it is common to see relatives from both parties engaged in RJ practices."

Among the survey participants in BC, NS, and BD, there is consensus on the inclusion of the supporters of victims and offenders in RJ processes. When asked about inclusion, a majority of the survey respondents shared that both "inclusion of victim supporters and inclusion of offender supporters" are very important to their RJ practices (see Table III).

\section{Community as Neighbours}

Community as neighbour indicates the people and place where RJ programs are located. As discussed in the literature review, community as neighbour is also known as macro community. This study finds the presence of general community members or neighbours in RJ practices in BC, NS, and BD. The passion, dedication, and optimism of RJ volunteers and practitioners sustained the growth of RJ with what Participant BC 4 calls "endless ridiculous optimism." In the context of a major funding crisis with both the federal and provincial government, these RJ volunteers and RJ practitioners did not lose their faith and hope in the programs. Participants BC 18, NS 8, and BD 4 shared several personal anecdotes and stories about this. Participant BC 18 recalled a vivid dream about Kingston Penitentiary, which represents the criminal justice system, as well as a dream about "five pins" to unlock the gridlock between the criminal justice system and RJ practitioners. Both Participant BC 18 and Participant NS 8 cannot imagine that they would one day retire from $\mathrm{RJ}$ volunteering because, to them, RJ work is "deeply spiritual" (Participant BC 18) and "meaningful" (Participants NS 8). Participant BC 18 passionately shared, "I don't have anything better to do. I don't think there is anything better to do. I find working in the field of restorative justice so fulfilling. So enriching. It's like the Hotel California-you can check out anytime you like but you can never leave."

Among the survey participants, the question of whether RJ should be "community-born, community-based, and community-led practice" led to some insights. Table IV shows that, among the survey participants in BD, 76\% strongly agreed, while in NS only about $42 \%$ strongly agreed with the statement that RJ should be community-born, community-based, and community-led.

\section{Additional Community Praxis in Restorative Justice}

Beyond these three types of communities-volunteer, circle of care, and neighbour - the scope or role of community in practice is ambiguous. This study suggests that a reflective community and a learning community are integral parts of community praxis, with reflective community explicitly bringing the concept of reflection and relationships into RJ, and learning community bringing theory. The findings of this study discussed below, particularly those from BC and NS, contribute to the understanding of community praxis that incorporates reflective and learning communities.

\section{Reflective Community in British Columbia}

An example of reflective community in $\mathrm{BC}$ was given by the group of people who used to meet frequently at the home of Liz Elliott (Participant BC 4) in Mission, BC. The key purpose of these gatherings was to share ideas, have meals together, build connections, and check in with each other. Key informant interviewees from BC shared clear insights into the role

TABLE II Community volunteers and the growth of restorative justice

\begin{tabular}{lc}
\hline \multicolumn{1}{c}{ Research Site } & Participants Who Believe Support from Volunteers is Very Important \\
\hline British Columbia (BC) & $56.41 \%$ \\
Nova Scotia (NS) & $60.61 \%$ \\
Bangladesh (BD) & $31.25 \%$ \\
\hline
\end{tabular}


TABLE III Circles of care and the growth of restorative justice

\begin{tabular}{lcc}
\hline \multicolumn{1}{c}{ Research Site } & Inclusion of Victim Supporters is Very Important & Inclusion of Offender Supporters is Very Important \\
\hline British Columbia (BC) & $56.76 \%$ & $51.35 \%$ \\
Nova Scotia (NS) & $51.52 \%$ & $54.55 \%$ \\
Bangladesh (BD) & $52.94 \%$ & $61.11 \%$ \\
\hline
\end{tabular}

TABLE IV Community as neighbour

\begin{tabular}{lccc}
\hline \multicolumn{1}{c}{ Research Site } & Strongly Agree & Agree & Strongly Disagree \\
\hline British Columbia (BC) & $51.22 \%$ & $34.15 \%$ & $0.00 \%$ \\
Nova Scotia (NS) & $42.42 \%$ & $36.36 \%$ & $3.03 \%$ \\
Bangladesh (BD) & $76.47 \%$ & $17.65 \%$ & $0.00 \%$ \\
\hline
\end{tabular}

Participant responses to the question "Should restorative justice be community-born, community-based, and community-led?"

of community in nurturing interpersonal relationships. Participant BC 3 and Participant BC 12 referred to these weekly meetings as "Sunday Supper." The meetings were reflective in nature. Participant BC 3 recalled that people from different walks of life used to attend, including students, community members, and prison inmates. According to Participant BC 3 , these meetings and discussions continued for years and had a transformative impact on people:

She [Liz Elliott] opened her house to the students, lay people and stuffs, AVPers and then everybody would have a good time at the place there and it was just great. Everybody would go back totally enthusiastic. It was fabulous, just incredible. That was really transformative.

Participant BC 12, who also attended these regular meetings, commented that they were not "structured" or "themebased." Both Participant BC 3 and Participant BC 12 reflected on the fact that the meetings were open to a diverse group of people and the discussions were lively, connecting, and relational. Host Liz Elliott's understanding of the importance of person-to-person relationships is reflected in her book: "I learned that the problems were much deeper than a flawed criminal justice system, and that our work needed to begin in our relationships with each other and the natural world, and most importantly, with ourselves" (Elliott, 2011, p. 1).

Furthermore, Participants BC 18 and BC 4 also experienced a sense of reflective community when a group of academics and practitioners formed BC RJ Charters, a group that met frequently at Simon Fraser University's Centre for Restorative Justice. One of the major successes of these meetings was the establishment of a restorative justice charter for BC. In 2003, after meeting many times, over $20 \mathrm{RJ}$ advocates formulated a Charter for Practitioners of Restorative Justice that was known as the BC RJ Charter and based on a consensus-based decisionmaking process. This charter articulated principles and values to guide RJ practices (Participant BC 18). As envisioned by the signatories, it represented a "living" and "breathing" document that would evolve and address the needs of the community (BC RJ Charter, 2003, p. 1). The BC RJ Charter includes the following: full, informed, and voluntary participation of all; do no further harm; diversity; caring and compassion; equality; healing; responsibility, truth, and honesty; consensus-based decision making; justice; inclusion; trust; safety, respect, and non-judgment; self-awareness and integrity; flexibility; empathy; interconnectedness of community; courage; humility; wellness; confidentiality; listening and sharing; peace; empowerment; and self-determination (BC RJ Charter, 2003, p. 2). According to Dyck (2010), the BC RJ Charter not only guides RJ programs with RJ values and principles, it also holds the practitioners accountable to the public.

In summary, the reflective community in BC evolved organically with the leadership of Liz Elliott at her house. Her worldviews on interpersonal relationships influenced the formation of this community. Unstructured, non-hierarchal, relational, open-to-anyone, and informal are some of its salient features.

\section{Learning Community in Nova Scotia}

The other community praxis that emerged in this study is the concept of a "learning community" (Participant NS 2). Professor Jennifer Llewellyn at the University of Dalhousie played an instrumental role in promoting the idea of a learning community. Unlike reflective community gatherings, learning community meetings are structured and agenda based. Participants in the NS learning community were mostly RJ academics, practitioners, and professionals.

One of the key objectives of the learning community in Nova Scotia RJ was "learning from each other in real time" (Participant NS 2). Funding from the Nova Scotia Restorative Justice Community University Research Alliance (NSRJCURA), contributed to the formation of this community. Academics, justice stakeholders from government agencies, and community members participated. The University of Dalhousie became the hub of such activity. Participant NS 2 eloquently summarized why the university setting became the place for a learning community:

the use [of] the university [Dalhousie] as a gathering point, as a place that people can convene. In our best moments, universities should be places where people are able to convene, to learn together, to generate knowledge together, and to mobilize that knowledge together, figure out what it means and what we should do about it. And it becomes a really quite powerful place I think because it's neutral space. So, we could bring partners together around a common 
cause, around looking at a common issue, around coming to reflect on where they are.

Participant NS 8 offered a similar sentiment, "I am sure everybody felt comfortable coming to Dalhousie for gatherings. Government folks, community members, police, and academics were attending these meetings. I think there is a sense of safety for all in a university setting." According to Participant NS 4, meetings are usually held once a month. Questions such as "what is working, what is not working, and what can be done restoratively to address newer challenges" are common themes discussed in learning community meetings (Participant NS 4).

Dalhousie University as a learning community became the hub for gathering, sharing, brainstorming, learning, relearning, and un-learning (Participant NS 8). As Participant NS 2 enthusiastically shared, in this learning community, "we can create time." A number of innovative RJ practices emerged in this way, through what Llewellyn and her colleagues (2013) have referred to as an "act of creative imagination" (p. 284).

An example of the successes of this learning community in Nova Scotia is the emergence of innovative practices and relational justice theory. The idea of learning in general is similar to this notion of community of learners. Communities of learners tend to focus on theatrical and conceptual aspects of knowledge along with reflection (Brown \& Campione, 1994).

Additionally, the success of the learning community in NS inspired RJ advocates and practitioners in other jurisdictions, such as Hull, in the United Kingdom, and Vermont, in the United States. According to Participant NS 2:

so I think that [learning community] was a significant model, I think it's the model that we're now trying to figure out how to build [to] support international learning communities in multiple jurisdictions ... how do we intentionally create these spaces and places where we can meet together and support one another, where we can convene and be connected... and who takes care of those connections to make sure that they keep happening and so that we know each other and we can learn from each other.

In summary, the ideal host of a learning community is a university/education setting. The essence of a learning community is mutual learning, mutual sharing, and co-creation. Meetings are structured and agenda- or theme-based. This study argues that learning community as community praxis could foster innovation and creativity in RJ.

\section{$\mathrm{CBO}$ s as Community in Bangladesh}

Bangladesh was a boon for the exploration of community in practice through the community-based organizations locally known as CBOs, which are not prevalent in British Columbia or Nova Scotia but would fall under community as volunteers. Bhuiyan et al. (2018) argue that "in Bangladesh, CBOs have been found to contribute in wide-ranging aspects, that is, management of natural resources, community empowerment, access to service delivery, rural infrastructure development, and so on" (p. 216).

Both key informant interviewees and survey participants shared thoughts about the role of CBOs in Bangladesh. When asked about the differences between NGOs and CBOs, Participant BD 4, who is involved with both, summed it up thus:

CBOs are more locally connected than NGOs. CBO members are also geographically located around the same area, whereas NGOs may have multiple offices in multiple locations... CBOs play an important role as RJ coordinator.

Participants BD 2 and BD 5 shared similar thoughts, and Participant BD 5 believed that villagers increasingly know RJ because "CBOs have the most natural access to villagers as they are relationally connected with them." Participant BD 2 added, "CBOs can even play a bridging role between the community members of different political parties. In this way, villagers and general community can trust the RJ process."

Survey participants also shared overwhelmingly positive views on CBOs in RJ in Bangladesh. Survey participants viewed CBOs' role in RJ as "the main pillar," "bridging partner," "main entry point," "catalyst," and "right door for victim and wrongdoer."

\section{Proposed Community Engagement Framework}

In light of the above discussion, this study proposes a community engagement framework (see Figure 1) grounded in the work of Block (2018) and McCold (2010), which proposes the idea of horizontal community and vertical community, building on Roche (2003) in a context of accountability in RJ. According to Roche (2003), horizontal accountability is related to informal community ties, whereas vertical accountability is connected with institutions such as courts or other regulatory agencies. Hoffmann-Lange (2012) also employed the terms horizontal and vertical accountability, with a similar meaning. Horizontal community is more informal and provides the space for Block's restorative community, in which individuals experience belonging physically, emotionally, and intellectually. This study argues that the horizontal community, in particular, resonates with the notion of Gemeinschaft (Tönnies, 1957), in which bonds and connection across community members occur naturally. Horizontal community also echoes what Durkheim (1933) refers to as organic community. This community solidifies the relational foundation. Vertical community, on the other hand, includes McCold's micro and

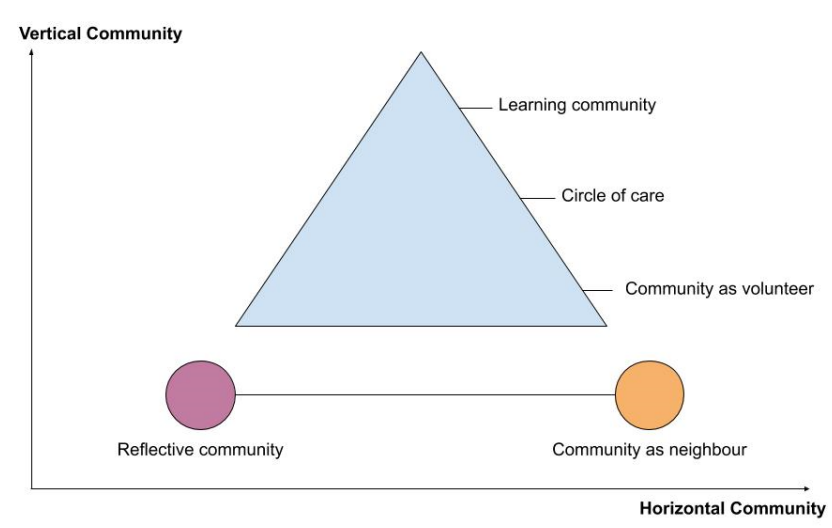

FIGURE 1 Proposed community engagement framework 
macro communities, which include community as a circle of care and community as volunteers. It also includes the learning community. In summary, a horizontal community nurtures the emotional aspect of community, while a vertical community is more formal and focuses on external elements, such as logistics, facilitation, and other supports needed for RJ practices.

This study proposes that both vertical community and horizontal community are needed for effective community engagement in RJ practices. Horizontal community includes reflective communities and community as neighbour, whereas vertical community includes learning communities, circles of care, and volunteers. The next section discusses each group in detail.

\section{Horizontal Community}

Horizontal community brings both reflection and theory into RJ practice. It is more informal and non-hierarchal than vertical community. Horizontal community includes reflective communities and community as neighbour.

\section{Reflective community}

Who: Passionate individuals who would like to nurture connection, empathy, and resiliency.

What: Monthly meetings with an agenda that can include a) opening circle and check-in, b) discussion about selfcare, and c) closing circle. Sharing meals and rituals are strongly recommended. Ideally hosted by an RJ visionary or enthusiast at their home, a community centre, or a neighbourhood home.

- Evaluation methods: Noticing the depth of connection and the consistency of attendance.

\section{Community as neighbour}

Who: Anybody living in a city or area where an RJ organization is located; involvement of local community members brings local ownership.

What: The RJ organization can host free community events that promote awareness of restorative justice, such as the Speak Out Series of the North Shore Restorative Justice Society (https://www.nsrj.ca/programs/ speak-out-series). Inviting neighbours to the organization's annual general meeting also brings rootedness to RJ practice.

- Evaluation methods: One way to assess neighbour participation is to see whether volunteer recruitment is increasing in a given neighbourhood. Tracking attendance at public events and monitoring participation levels from the local community can also be an effective means of assessment.

\section{Vertical Community}

Vertical community is more structured and formal than horizontal community. It includes circles of care and volunteers. Roles and meetings are more structured.

\section{Learning community}

Who: Justice professionals, RJ advocates, academics, and practitioners.

What: Meetings every three months to explore a number of questions and issues, including what is working, what is not working, and what can be done to foster innovation and creativity. University settings are generally the ideal space for learning-community gatherings.

Evaluation methods: Documenting innovative RJ practices.

\section{Circles of care}

Who: Friends, family members, and supporters of the victims and offenders.

What: Offering empathy and support. The RJ organization can share a brief document outlining the role of the circle of care so that victims and offenders understand how to request support from their circle of care.

- Evaluation methods: Tracking the number of participants in circles of care.

\section{Community as volunteer}

Who: Trained volunteers serving in an RJ organization as board members, advisors, facilitators, coordinators, and event managers. In the context of Bangladesh, CBOs are part of this community.

What: Each volunteer may have a distinct role and task. Evaluation circle: Each organization may have a specific standard practice to assess volunteer performance, retention strategies, and feedback.

\section{Guiding Principles}

The guiding principles for both horizontal and vertical communities are developed in the Relational Theory of Justice (RTJ). These include, but are not limited to, being a) relationally focused, b) comprehensive and holistic, c) inclusive and participatory, d) responsive, e) focused on taking responsibility, f) collaborative and non-adversarial, and g) forward-focused (Llewellyn \& Morrison 2018, p. 348). This study assumes that these guiding principles would contribute to enhancing and nurturing equality of relationships and respect and dignity between and among all types of communities and justice stakeholders.

This research suggests that implementation of the proposed community engagement framework (Figure 1) would contribute to a fundamental shift, starting with extending the ownership of RJ practice from a few individuals out into the community and moving from dependency on RJ experts into co-creation. Block (2018) clearly articulates the scope of this shift:

This shift has important consequences for our communities. It offers to return politics to public service and restore trust in leadership. It moves us from having faith in professionals and those in positions of authority to having faith in our neighbours. It takes us into a context of hospitality, wherein we welcome strangers rather than believing we need to protect ourselves from them. It changes our mind-set from valuing what is efficient to valuing belonging. (p. 57)

The proposed community engagement framework is important for a number of reasons. First, it adds clarity regarding the role of community in RJ. Second, this proposed framework emphasizes both relational and creative aspects of RJ. For example, reflective community amplifies relationship, while 
learning community provokes innovation and creativity. This study posits that by employing the guiding principles of the relational theory of justice, the quality of relationships will significantly improve. Finally, by outlining Who, What, and Evaluation Methods, this framework offers a viable model for community engagement in RJ. A rigorous study with more research participants can percolate further understanding of the proposed community engagement framework and strengthen Block's notion of restorative community (2018).

\section{CONCLUSION}

Responding to the research question on the role of community in $\mathrm{RJ}$, this paper examined existing community praxis in three places and highlighted the concepts of reflective community from British Columbia and learning community from Nova Scotia. It argued that the presence of a reflective community solidified bonds and relationships, while a learning community contributed to innovation and creativity. The ideas of community in Bangladesh and Canada share similarities and also exhibit differences. For example, in Canadian RJ, the role of communities, reflective and learning, is somewhat informal. Building connection and fostering relationship and care for each other are the major features of these communities. In Bangladesh, on the other hand, the role of communities as CBOs is somewhat formal in nature but locally rooted in NGOs. This study is significant because it proposes a community engagement framework which consists of both a less formal horizontal community, which includes reflective community and community as neighbour, and a more formal vertical community, which includes learning community, circle of care, and volunteers. Inclusion of both horizontal and vertical communities not only enhances the quality of relationship among all stakeholders in RJ, it fosters innovative practices in RJ. A study with more research participants will add depth to the understanding of horizontal community and vertical community. Future studies can also examine the community's role in RJ organizations in other provinces and territories in Canada

\section{ACKNOWLEDGEMENTS}

The author would like to express deep gratitude to Dr. Brenda Morrison of Simon Fraser University, BC, and Professor Jennifer Llewellyn of Dalhousie University, NS, and Sarder M. Asaduzzaman of UNDP, Bangladesh, for their guidance and rigorous feedback for this research.

\section{CONFLICT OF INTEREST DISCLOSURES}

The authors declare that there are no conflicts of interest.

\section{AUTHOR AFFILIATIONS}

* Department of Justice Studies, University of Regina, Regina, SK, Canada.

\section{REFERENCES}

Abramson, L., \& Beck, E. (2010). Using conflict to build community: Community conferencing. In E. Beck, N. Kropf, \& P. Leonard (Eds.), Social work and restorative justice: Skills for dialogue, peacemaking, and reconciliation (pp. 149-174). Oxford University Press.

Anderson, M., \& Freebody, K. (2012). Developing communities of praxis: Bridging the theory practice divide in teacher education. McGill Journal of Education, 47(3), 359-377.
Baskin, D. R., \& Sommers, I. (1990). Ideology and discourse: Some differences between state-planned and community-based justice. Law and Human Behaviour, 14(3), 249-268.

BC RJ Charter. (2003). A charter for practitioners of restorative justice. Paper presented at the 6th International Conference on Restorative Justice. June 2003. Centre for Restorative Justice, Simon Fraser University, Burnaby, BC, Canada.

Beck, E. (2012). Transforming communities: Restorative justice as a community building strategy. Journal of Community Practice, 20, 380-401.

Bhuiyan, M., Hassan, S., \& Islam, K. (2018). Role of community-based organisations in promoting democratic local governance at the grassroots in Bangladesh. Journal of Development Policy and Practice, 3(2), 215-224.

Block, P. (2018). Community: The structure of belonging. Berrett-Koehler Publishers

Blodgett, A., Schinke, R., Fisher, L., Wassengeso George, C., Peltier, D., Ritchie, S., \& Pickard, P. (2008). From practice to praxis: Communitybased strategies for aboriginal youth sport. Journal of Sport \& Social Issues, 32(4), 393-414.

Bolivar, D. (2012). Community of care from a victim perspective: A qualitative study. Contemporary Justice Review, 15(1), 17-37.

Braithwaite, J. (1989). Crime, shame, and reintegration. Cambridge University Press.

Braithwaite, J. (2000). Shame and criminal justice. Canadian Journal of Criminology, 42(3), 281-298.

Braithwaite, J. (2002). Setting standards for restorative justice. The British Journal of Criminology, 42(3), 563-577.

Broadhead, R. S., \& Rist, R. C. (1976). Gatekeepers and the social control of social research. Social Problems, 23(3), 325-336.

Brown, A. L., \& Campione, J. C. (1994). Guided discovery in a community of learners. In K. McGilly (Ed.), Classroom lessons: Integrating cognitive theory and classroom practice (pp. 229-270). MIT Press.

Burford, G. (2018). Keeping complexity alive: Restorative and responsive approaches to culture change. The International Journal of Restorative Justice, 113), 356-371

Christie, N. (1977). Conflicts as property. The British Journal of Criminology, 1-15

Day, G. (2006). Community and everyday life. Routledge.

Daly, K. (2016). What is restorative justice? Fresh answers to a vexed question. Victims \& Offenders, 17(1), 9-29.

Dhami, M. K, \& Joy, P. (2007). Challenges to establishing volunteer-run, community-based restorative justice programs. Contemporary Justice Review, 10(1), 9-22.

Dickson-Gilmore, E., \& LaPrairie, C. (2005). Will the circle be unbroken? Aboriginal communities, restorative justice and the challenges of conflict and change. University of Toronto Press.

Durkheim, E. (1933). The division of labour in society. Translated by George Simpson. Free Press of Glencoe, IL. (First published 1893).

Dyck, D. (2010). Are we-practitioners, advocates-practicing what we preach? In H. Zehr \& B. Toews (Eds.), Critical issues in restorative justice (pp. 277-291). Lynne Rienner Publishers.

Dzur, A. W., \& Olson, S. M. (2004). The value of community participation in restorative justice. Journal of Social Philosophy, 35(1), 91-107.

Elliott, E. M. (2011). Security with care: Restorative justice and healthy societies. Fernwood Publishing.

Evans, S. (2015). The community psychologist as critical friend: Promoting critical community praxis. Journal of Community \& Applied Social Psychology, 25(4), 355-368.

Freire, P. (1972). Pedagogy of the oppressed. Herder and Herder.

Gavrielides, T., \& Artinopoulou, V. (2013). Reconstructing restorative justice philosophy. Taylor \& Francis Group. 
Gerkin, P. M. (2012). Who owns this conflict? The challenge of community involvement in restorative justice. Contemporary Justice Review, 15(3), 277-296.

Green, S., Johnstone, G., \& Lambert, C. (2013). What harm, whose justice?: Excavating the restorative movement. Contemporary Justice Review, 16(4), 445-460.

Hesse-Biber, S. N. (2010). Qualitative approaches to mixed methods practice. Qualitative Inquiry, 16(6), 455-468.

Hoffmann-Lange, U. (2012). Vertical and horizontal accountability of global elites: Some theoretical reflections and a preliminary research agenda. Historical Social Research / Historische Sozialforschung, 37(1), 193-208.

Howe, R. (2004). A critique of experimentalism. Qualitative Inquiry, $10(1), 42-61$.

Karp, D. R., \& Clear, T. R. (2002). What is community justice? Case studies of restorative justice and community supervision. SAGE Publications.

Karp, D. R., \& Drakulich, K. M. (2003). Minor crime in quaint setting: Practices, outcomes, and limits of Vermont reparative probation boards. Criminology \& Public Policy, 3, 655-686.

Lederach, J. P. (1997). Building peace: Sustainable reconciliation in divided societies. United States Institute of Peace Press.

Lofton, B. P. (2010). Does restorative justice challenge systemic injustice? In H. Zehr \& B. Toews (Eds.), Critical issues in restorative justice (pp. 381-389). Lynne Rienner Publishers.

Llewellyn, J. (2011). Restorative justice: Thinking relationally about justice. In J. Downie \& J. Llewellyn (Eds.), Being relational: reflections on relational theory and health law (pp. 89-108). UBC Press.

Llewellyn, J., Archibald, B., Clairmont, D., \& Crocker, D. (2013). Imagining success for a restorative approach to justice: Implications for measurement and evaluation. Dalhousie Law Journal, 36(2), 281-316.

Llewellyn, J., \& Morrison, B. (2018). Deepening the relational ecology of restorative justice. The International Journal of Restorative Justice, $7(3), 343-355$

Maglione, G. (2017). Communities at large: An archaeological analysis of the 'community' within restorative justice policy and laws. Critical Criminology, 25(3), 453-469.

McCold, P. (2010). What is the role of community in restorative justice theory and practice? In H. Zehr \& B. Toews (Eds.), Critical issues in restorative justice (pp. 155-172). Lynne Rienner Publishers.

McKinney, J. C. (1966). Constructive typology and social theory. AppletonCentury-Crofts.

Moniruzzaman, M. (2009). Party politics and political violence in Bangladesh: Issues, manifestation and consequences. South Asian Survey, 16(1), 81-99.
Morrison, B. (2006). School bullying and restorative justice: Toward a theoretical understanding of the role of respect, pride, and shame. Journal of Social Issues, 62(2), 371-392.

Morrison, B., \& Vaandering, D. (2012). Restorative justice: Pedagogy, praxis, and discipline. Journal of School Violence, 11(2), 138-155.

Morrison, B., Asadullah, M., \& Pawlychka, C. (2020). Juvenile justice and restorative justice: Reflecting on developments in British Columbia. In J. Winterdyk \& R. Smandych (Eds.), Youth at risk and youth justice: A Canadian overview (pp. 436-460). Oxford University Press.

Osborne, T. (2017). Public political ecology: A community of praxis for earth stewardship. Journal of Political Ecology, 24(1), 843-860.

Pavlich, G. (2010). What are the dangers as well as the promises of community involvement? In H. Zehr \& B. Toews (Eds.), Critical issues in restorative justice (pp. 155-172). Lynne Rienner Publishers.

Perry, C. (1986). A proposal to recycle mechanical and organic solidarity in community sociology. Rural Sociology, 51(3), 263-277.

Pranis, K. (1995, December 31). Building community support for restorative justice: Principles and strategies. International Institute of Restorative Practices (IIRP). Retrieved July 2, 2019, from https://www.iirp.edu/ news/building-community-support-for-restorative-justice-principlesand-strategies

Pranis, K. (2007). Restorative values. In G. Johnstone \& D. W. Van Ness (Eds.), Handbook of restorative justice (pp. 59-74). Willan.

Prilleltensky, I. (2001). Value-based praxis in community psychology: Moving toward social justice and social action. American Journal of Community Psychology, 29(5), 747-778.

Roche, D. (2003). Accountability in restorative justice. Oxford University Press. Rosenblatt, F. F. (2015). The role of community in restorative justice. Routledge.

Rossner, M., \& Bruce, J. (2016). Community participation in restorative justice: Rituals, reintegration, and quasi-professionalization. Victims \& Offenders: An International Journal of Evidence-Based Research, Policy, and Practice, 1711), 107-125.

Schatz, M. (2013). Community members: Vital voices to the restorative justice process. In K. S. van Wormer \& L. Walker (Eds.), Restorative justice today: Practical applications (pp. 113-120). SAGE Publications.

Stuart, B. D. (1998). Key differences: Courts and community circles. The Justice Professional, 11, 89-116.

Tönnies, F. (1957). Community and society: Gemeinschaft und Gesellschaft. Translated and edited by Charles P. Loomis. Michigan State University Press.

Tyler, T. R., \& Blader, S. (2000). Cooperation in groups: Procedural justice, social identity, and behavioral engagement. Psychology Press.

Walgrave, L. (2008). Restorative justice, self-interest and responsible citizenship. Willan. 